to add this consideration to an extending list of host factors that bear on host-parasite interactions.

This work was supported by grant $\mathrm{K} / \mathrm{MRS} / 50 / \mathrm{C} 22$ from the Biomedical Research Committee, Scottish Home and Health Department and by grants G81/103811/SB and G979/74/S from the Medical Research Council.

We thank the Blood Transfusion Service, Royal Infirmary, Edinburgh for supplying reagents for blood grouping and determination of secretor state and for undertaking random verification checks on selected saliva (50) and plasma (48) samples; Dr J McMurdoch and Dr J A Gray for permission to study their patients; the doctors and staff of Ward 14, City Hospital, Edinburgh; and Professor J G Collee and Messrs A McGowan and G Neill for their help and advice.

\section{References}

1 Barua D, Paguio AS. ABO blood group and cholera. Ann Hum Biol 1977; 4:489-92.

${ }^{2}$ Socha W; Bilinska M, Kaczera Z, Padjak E, Stankiewicz D. Escherichia coli and ABO blood groups. Folia Biol (Krakow) 1969;17:259-69.

${ }^{3}$ Robinson MG, Tolchrin D, Halpern C. Enteric bacterial agents and the ABO blood groups. Am $\mathcal{F}$ Hum Genet $1971 ; 23: 135-45$.

${ }^{4}$ Cruz-Coke R, Parades L, Montengro A. Blood groups and urinary microorganisms. F Med Genet 1965;2:185-8.

${ }^{5}$ Foster MT, Labrum AH. Relation of infection with Neisseria gonorrhoeae to blood groups. $\mathcal{F}$ Infect Dis 1976;133:329-30.

6 Miler JJ, Novotny P, Walker PD, Harris JRW, MacLennan IPB. Neisseria gonorrhoeae and ABO isohaemagglutinins. Infect Immun 1977; $15: 713-9$.

${ }^{7}$ Haverkorn MJ, Goslings WRO. Streptococci ABO blood groups and secretor status. Am $\mathcal{F}$ Hum Genet 1969;21:360-75.

${ }^{8}$ Pradhan AC, Chawla TN, Samuel KC, Pradhan S. The relationship between periodontal disease and blood groups and secretor status. $\mathcal{f}$ Periodont Res 1971;6:194-300.

${ }^{9}$ Chaudhuri A, Das Adchickary CR. Possible role of blood group secretory substances in the aetiology of cholera. Trans $R$ Soc Trop Med Hyg $1978 ; 72: 664-5$.
${ }^{10}$ Kopeć AC. The distribution of the blood groups in the United Kingdom. Oxford: Oxford University Press, 1970:26.

11 Mollinson PL. Blood transfusion in clinical medicine. 6th ed. Oxford: Blackwell, 1979:414-82.

12 Armitage P. Statistical methods in medical research. Oxford: Blackwell, $1971: 375$

${ }^{13}$ Lincoln PJ, Dodd BE. Variation in secretor and Lewis type frequencies within the British Isles. $\mathcal{F}$ Med Genet 1972;9:43-5.

14 Springer GF, Williamson P, Brandes WC. Blood group activity of Gramnegative bacteria. F Exp Med 1961;113:1177-93.

${ }^{15}$ Muschel L, Osawa E. Human blood group substances B and Escherichia coli 086. Proc Soc Exp Biol Med 1959;101:614-7.

${ }^{16}$ Springer GF. Importance of blood group substances in interactions between man and microbes. Ann NY Acad Sci 1970;169:134-52.

17 Springer GF. Blood group and Forssman antigenic determinants shared between microbes and mammalian cells. Prog Allergy 1971;15:9-77.

18 Drach GW, Reed WP, Williams RC. Antigens common to human and bacterial cells : urinary tract pathogens. F Lab Clin Med 1971 ;78:725-35.

19 Check JH, O'Neill EA, O'Neill KE, Fuscaldo KE. Effect of anti-B antiserum on the phagocytosis of Escherichia coli. Infect Immun 1972;6: 95-6.

${ }^{20}$ Drach GW. Antigens common to human and bacterial cells: tolerance or resistance to urinary and surgical infections. Surg Forum 1971;22:67-8.

${ }^{21}$ Grundbacher FJ, Shreffler DC. Effects of secretor, blood and serum groups on isoantibody and immunoglobulin levels. Am F Hum Genet $1970 ; 22: 194-202$.

22 Grundbacher FJ. Immunoglobulins, secretor status and the incidence of rheumatic fever and rheumatic heart diseases. Hum Hered 1972;25: 399-404.

${ }^{23}$ Kalinowski $M$. Urinary elimination of group substances $\mathrm{ABO}(\mathrm{H})$ in different renal diseases. Folia Haematol (Liepz) 1972;100:144-63.

${ }^{24}$ Boat TF, Davis J, Stern RC, Cheng PW. Effect of blood group determinants on binding of human salivary mucous glycoproteins to influenza virus. Biochim Biophys Acta 1978;540:127-33.

${ }^{25}$ Weir DM, Blackwell CC, McLean CA. Impaired bacterial binding to peritoneal exudate cells from mice with alloxan induced diabetes. fournal of Clinical and Laboratory Immunology 1981 ;5:37-40.

${ }^{26}$ Rolleston GL, Shannon FT, Utley JF. Relationship of infantile cytoureteric reflux to renal damage. $\mathrm{Br} \mathrm{Med} \mathcal{F} 1970 ; \mathrm{i}: 460-3$.

(Accepted 19 April 1982)

\title{
Severe hypoglycaemia due to combined use of parenteral nutrition and renal dialysis
}

\author{
J D B MILLER, J BROOM, G SMITH
}

\begin{abstract}
A 24-year-old woman who had sustained serious injuries in a road traffic accident required renal dialysis daily and was fed intravenously with a solution containing $25 \%$ dextrose. Subsequently insulin had to be added to the parenteral fluid to maintain blood glucose concentrations at physiological values. On one occasion parenteral feeding was continued until dialysis was started; she became comatose and the plasma glucose concentration was found to be $<1 \mathrm{mmol} / 1(18 \mathrm{mg} / 100 \mathrm{ml})$. She responded rapidly to a $50 \mathrm{ml}$ intravenous bolus of $50 \%$ dextrose.

When parenteral feeding and dialysis are used simultaneously glucose passes across the semi-permeable membrane from the blood to the dialysate so that hypoglycaemia may occur. Insulin added to the parenteral fluid further decreases blood glucose concentrations. Stopping parenteral feeding 30-45 minutes before dialysis is started eliminates this danger of hypoglycaemia.
\end{abstract}

Department of Surgery, University of Aberdeen, Aberdeen AB9 2ZD

J D B MILLER, CHM, FRCs, senior lecturer in surgery

J BROOM, MB, CHB, lecturer in surgery and chemical pathology

G SMITH, DSC, MD, regius professor of surgery

\section{Introduction}

Parenteral nutrition and renal dialysis are sometimes used together to treat severely ill patients. These supportive techniques may individually cause fluid, electrolyte, and metabolic disturbances; we propose that in the case described below their combined use caused severe and unexpected hypoglycaemia.

\section{Case report}

A 24-year-old woman was injured in a road traffic accident and sustained a traumatic pneumothorax, a fractured pelvis, spinal damage with paraplegia, a ruptured and in parts devitalised small intestine, and a ruptured thoracic aorta. She survived aortic repair with a Dacron graft, small-bowel resection, and drainage of the pneumothorax. Her postoperative course was complicated by ventilatory difficulties, septicaemia, and acute renal failure. From the third day after admission she required daily renal dialysis for three weeks. During this time she was fed intravenously with a solution containing $25 \%$ dextrose and $\mathbf{4} \cdot 25 \%$ amino-acids delivered via a subclavian vein. Ten days after admission she underwent a further operation for drainage of an empyema. The stress associated with the initial injury, and subsequent septic complications, required that soluble insulin in doses of 15-25 U/1 be added to the parenteral nutrition fluid to maintain the blood glucose concentration at physiological values. A total of 2.0-2.5 1 parenteral feed was delivered daily over 18 hours 
since none was given during dialysis. For technical reasons $35-40$ minutes elapsed from the time parenteral feeding was stopped until dialysis was established.

On the 13th day after admission, when dialysis had been in progress for some 50 minutes, she complained of drowsiness and rapidly became comatose. On that day $20 \mathrm{U}$ soluble insulin had been added/1 parenteral fluid, this amount having been calculated from her previous blood glucose concentrations and insulin requirements. Unlike on previous occasions, however, the infusion had been allowed to continue until dialysis was established.

A capillary blood sample was taken and glucose concentration determined with Dextrostix (Miles Laboratories Ltd, Slough); this gave a negative result. Simultaneously a venous blood sample was sent to the emergency biochemistry laboratory, and the plasma glucose concentration was reported as $<1 \mathrm{mmol} / \mathrm{l}(18 \mathrm{mg} / 100 \mathrm{ml})$. She responded rapidly to a $50 \mathrm{ml}$ intravenous bolus of $50 \%$ dextrose and suffered no permanent ill effect from the hypoglycaemic episode. Six weeks later she was discharged home having recovered full gastrointestinal and renal function but with residual paraplegia.

\section{Discussion}

Addition of insulin to intravenous feeding solutions is established practice in many centres ${ }^{1}$ when stress from trauma or sepsis causes reduced use of exogenously supplied carbohydrate. Experience has shown that because the insulin is delivered as an additive to the hypertonic dextrose hypoglycaemia is not a problem even if the infusion is stopped abruptly. ${ }^{2}$ In the case reported, however, dialysis was already in progress when the infusion was stopped and the patient then had both a mildly raised blood glucose concentration owing to the infusion of $25 \%$ glucose and an appreciable blood concentration of exogenously supplied insulin. The solution used for dialysis contained no glucose and so a shift of glucose occurred across the semi-permeable membrane from the blood to the dialysate, resulting in a rapid reduction in the blood glucose concentration. The exogenous insulin, having too great a molecular size to cross the membrane, remained in the patient's circulation to reduce the blood glucose concentration further to critical hypoglycaemic levels.

If the infusion is stopped $30-45$ minutes before dialysis is started blood glucose and insulin concentrations are allowed to fall naturally and simultaneously so that even if dialysis subsequently depresses the blood glucose concentration there is insufficient residual exogenous insulin, with its physiological half life of 20-30 minutes, ${ }^{3}$ to have a pronounced hypoglycaemic effect.

This case prompted us to make changes in our management of such patients, and we have not subsequently encountered this hypoglycaemic complication.

\section{References}

${ }^{1}$ Blackburn GL, Maini BS, Pierce EC. Nutrition in the critically ill patient. Anesthesiology 1977;47:181-94.

2 Benotti PN, Bothe A, Miller JDB, Bistrian BR, Blackburn GL. Cyclic hyperalimentation. Compr Ther 1976;2:27-30.

${ }^{3}$ Grodsky GM, Forsham PH. Insulin and the pancreas. Annu Rev Physiol $1966 ; 28: 347-52$.

\title{
Effect of ultraclean air in operating rooms on deep sepsis in the joint after total hip or knee replacement: a randomised study
}

\author{
O M LIDWELL，E J L LOWBURY，W WHYTE，R BLOWERS，S J STANLEY，D LOWE
}

\begin{abstract}
In a multicentre study of sepsis after total hip or knee replacement the operations performed by each surgeon were allocated at random between control and ultracleanair operating rooms. Records were obtained from over 8000 such operations.

In the patients whose prostheses were inserted in an operating room ventilated by an ultraclean-air system
\end{abstract}

\footnotetext{
Central Public Health Laboratory, Colindale, London, and Harvard Hospital, Salisbury, Wiltshire

O M LIDWELL, DPHIL, formerly deputy director, Cross-infection Reference Laboratory

MRC Burns Unit and University of Aston, Birmingham

E J L LOWBURY, DM, FRCPATH, honorary visiting professor of medical microbiology

Building Services Research Unit, University of Glasgow W WHYTE, BSC, bacteriologist

MRC Clinical Research Centre, Harrow, Middlesex HA1 3UJ

R BLOWERS, MD, FRCPATH, formerly head of division of hospital infection

MRC Biostatistics Unit, Hills Road, Cambridge

S J STANLEY, BSC, statistician

D LOWE, MSC, MIS, statistician
}

the incidence of joint sepsis confirmed at reoperation within the next one to four years was about half that of patients who had had the operation in a conventionally ventilated room at the same hospital. When whole-body exhaust-ventilated suits had been worn by the operating team in a theatre ventilated by an ultraclean-air system the incidence of sepsis was about a quarter of that found after operations performed with conventional ventilation. When all groups in the trial were considered together the analysis showed deep sepsis after 63 out of 4133 operations in the control group (1.5\%) and after 23 out of 3922 operations in the ultraclean-air groups $(0 \cdot 6 \%)$ (ratio $2 \cdot 6$, $95 \%$ confidence limits $1 \cdot 6-4 \cdot 2 ; p<0.001)$.

The design of the study did not include a strictly controlled test of the effect of prophylactic antibiotics, but their use was associated with a lower incidence of sepsis than in patients who had received no antibiotic prophylaxis at their operations $(0.6 \%(34 / 5831)$ v $2.3 \%$ (52/2221); ratio $4 \cdot 0)$.

\section{Introduction}

The importance of airborne bacteria in the operating room as a possible source of surgical wound sepsis has been a subject of controversy for over a century. With the development of 